\title{
Feeding ecology of Dash-dot Tetra Hemigrammus belottii (Steindachner 1882) (Characiformes: Characidae) in the streams of the Urucu River basin, central Amazonia, Brazil
}

\author{
Andrey Felipe Gomes Gonçalves ${ }^{1}$, Bruno da Silveira Prudente ${ }^{2}$, \\ Fernando da Silva Carvalho Filho ${ }^{3}$ \& Luciano Fogaça de Assis Montag ${ }^{1,4}$ \\ ${ }^{1}$ Instituto de Ciências Biológicas, Universidade Federal do Pará-UFPA, \\ Rua Augusto Corrêa, 01, Guamá, CEP 66075-110, CP 479, Belém, PA, Brazil \\ ${ }^{2}$ Programa de Pós-graduação em Zoologia, Museu Paraense Emílio Goeldi-MPEG, \\ Universidade Federal do Pará-UFPA, Av. Perimetral, 1901, Montese, \\ CEP 66077-830, CP 399, Belém, PA, Brazil \\ ${ }^{3}$ Departamento de Zoologia, Setor Entomologia, Museu Paraense Emílio Goeldi-MPEG, \\ Av. Perimetral, 1901, Montese, CEP 66077-830, CP 399, Belém, PA, Brazil \\ ${ }^{4}$ Corresponding author: Luciano Fogaça de Assis Montag, e-mail: montag@ufpa.br
}

GONÇALVES, A.F.G., PRUDENTE, B.S., CARVALHO FILHO, F.S. \& MONTAG, L.F.A. Feeding ecology of Dash-dot Tetra Hemigrammus belottii (Steindachner 1882) (Characiformes: Characidae) in the streams of the Urucu River basin, central Amazonia, Brazil. Biota Neotrop. (13)3: http://www.biotaneotropica.org. br/v13n3/en/abstract?article+bn03113032013

Abstract: The present study describes aspects of feeding ecology of Dash-dot Tetra Hemigrammus belottii (Characiformes: Characidae) collected in the Urucu River basin in Coari, Amazonas (Brazil), aims to respond the following question: What is the influence of hydrological periods (dry and wet) and spatial distribution in the diet of $H$. belottii ? The specimens were collected between 2006 and 2009 in seven streams in the Urucu basin using standard capture methods. Their stomachs were removed for diet composition analyses. The alimentary items were weighed and identified for subsequent analyzes related to feeding intensity by repletion index (RI\%) and importance by alimentary index (AIi\%). A total of 227 specimens were analyzed, with a mean standard length of $16.5 \pm 5.6 \mathrm{~mm}$. The RI\% values indicated that $H$. belottii fed more intensively during the dry season. The principal items in the diet were Formicidae $(\mathrm{IAi} \%=69.6)$, fragments of allochthonous exoskeleton $(\mathrm{IAi} \%=17.7)$, and Coleoptera $(\mathrm{IAi} \%=6.0)$. The composition of the diet did not vary significantly between seasons or among habitats, which may be related to the abundance of the items exploited by the species throughout the year.Hemigrammus belottii showed a generalist insectivore feeding habits which was mainly composed by allochthonous item.

Keywords: allochthonous item, Amazon basin, trophic ecology.

GONÇALVES, A.F.G., PRUDENTE, B.S., CARVALHO FILHO, F.S. \& MONTAG, L.F.A. Ecologia alimentar de Hemigrammus belottii (Steindachner 1882) (Characiformes: Characidae) em riachos da bacia do Rio Urucu, Amazônia Central, Brasil. Biota Neotrop. (13)3: http://www.biotaneotropica.org.br/v13n3/pt/ abstract?article+bn03113032013

Resumo: O presente estudo descreve a dieta da espécie Hemigrammus belottii (Characiformes: Characidae) coletados na bacia do Rio Urucu no município de Coari, Amazonas, (Brasil), buscando responder o seguinte questionamento: Qual a influência dos períodos hidrológicos (seco e chuvoso) e da distribuição espacial na dieta de H. belottii ? Os espécimes tiveram seus estômagos retirados e os itens alimentares pesados e identificados para posteriores análises relacionadas à intensidade alimentar, pelo Índice de Repleção (IR\%) e pelo índice de importância alimentar (IAi\%). Foi analisado um total de 227 espécimes, com comprimento padrão médio de $16,54 \mathrm{~mm} \pm 5,6 \mathrm{~mm}$. Baseado no IR\% verificou-se para $H$. belottii uma maior intensidade alimentar durante o período da seca. A dieta da espécie foi composta predominantemente pelos itens Formicidae $(\operatorname{IAi} \%=69,6)$, fragmento de exoesqueleto alóctone (IAi $\%=17,7)$ e Coleoptera (IAi $\%=6,0)$, com sua composição se mostrando independente de períodos hidrológicos e de sua distribuição espacial, que pode ser atribuído à alta disponibilidade de itens alimentares utilizados pela espécie durante o ano todo. De um modo geral $H$. belottii evidenciou um hábito alimentar insetívoro generalista, com predomínio de itens de origem alóctone.

Palavras-chave: itens alóctones, bacia Amazônica, ecologia trófica. 


\section{Introduction}

Studies of feeding ecology provide important insights into the biology of a species, which may be extremely relevant to the conservation of not only the taxon itself, but also the ecosystems it inhabits (Barreto \& Aranha 2006) enabling a better understanding of the relation among fishes and their habitats. Relatively few studies of this type are available for the complex network of Brazilian streams, considering that most fieldwork has been conducted in large bodies of waters, such as major rivers and reservoirs (Esteves \& Aranha 1999, Braga et al. 2012).

The term "igarapé" is used to refer to minor watercourses (streams) in the Brazilian Amazon region, which are generally characterized by low primary productivity, given that the riparian forest tends to block out much of the solar radiation (Walker 1998, Castro 1999). Given this, many fish species found in igarapés feed primarily on resources derived from the surrounding vegetation, such as fruit and terrestrial insects (Castro 1999).

The fish fauna of the Neotropics is dominated by relatively unspecialized opportunist species, which feed on a wide variety of resources, the availability and abundance of which may vary considerably over time and through space, associated with fluctuations in physical-chemical variables and the productivity of the environment (Lowe-McConnell 1999, Lima \& Behr 2010). However, Knöopel (1970) found no seasonal variation in the composition of the diets of fishes in Amazonian streams, and attributed this finding to the availability of feeding resources in this environment, as well as the pronounced spatial stratification related to the availability of a wide range of different microhabitats, which was corroborated by other authors (Wootton 1992, Anjos 2005).

Given that the Characidae is one of the most common fish families in the igarapés of the Central Amazon region (Espírito-Santo et al. 2009), the present study focused on the feeding ecology of the characid Hemigrammus belottii in the minor watercourses of the Urucu basin in Coari, in the Brazilian state of Amazonas, evaluating the influence of hydrological season and spatial variation in the feeding habit of species. Specifically, the study aims to respond the following questions: (i) what is the composition of diet of $H$. belottii in the igarapés of the Urucu basin? (ii) Is the feeding intensity and diet composition of this species in the Urucu basin dependent on the hydrological season (wet and dry season)? and (iii) Is the diet composition of $H$. belottii influenced by spatial variation found in the igarapés of the Urucu basin?

\section{Material and Methods}

\section{Study area}

The present study focused on the streams of the basin of the Urucu River, a tributary of the Coari River which, in turn, flows into the right margin of the Solimões (Amazon) River (Figure 1). The study area is located within the Juruá-Purus interfluvium, and is characterized by swampy areas interspersed with terra firme forest. The climate is humid tropical, consistent with subtype $\mathrm{Am}$ in the Köppen classification system, characterized by excessive rainfall during some months, with one or two months of precipitation lower than $60 \mathrm{~mm}$ (Ataíde et al. 2004). Mean annual precipitation is approximately $2300 \mathrm{~mm}$, the majority of which $(1504.1 \mathrm{~mm}$ ) falls between December and May (wet season), with only $729.9 \mathrm{~mm}$ occurring between June and November (Ataíde et al. 2004).

\section{Data analysis}

The composition of the diet of $H$. belottii was analyzed based on specimens collected in 11 different sectors located within seven distincts classified as first to third order (Strahler 1957) streams of the basin of the Urucu River. The specimens were collected between 2006 and 2009 in the dry (July, August, and September) and wet seasons (November and December) during five expeditions.

For better characterizations of each collecting station, the physical-chemical characteristics $\left(\mathrm{pH}\right.$ and conductivity, $\left.\mu \mathrm{S} . \mathrm{cm}^{-1}\right)$ and structural traits (stream width and depth in meters) of the streams were recorded (Table 1). Complementary information on the characteristics of each sector was also obtained - hydrodynamics (running or still water) and the predominant substrate.

Specimens were collected using drag nets $(3 \mathrm{~mm}$ mesh) and hand-nets ( $2 \mathrm{~mm}$ mesh) with a standardized sampling effort of 50 and 100 casts, respectively. The specimens collected were fixed in $10 \%$ formalin and conserved in $70 \%$ ethanol before being deposited in the ichthyological collection of the Museu Paraense Emílio Goeldi (MPEG) in Belém, Brazil (see Appendix).

Basic morphological measurements were taken for each specimen, including standard length (SL, in $\mathrm{mm}$ ) and body weight (Wt, in $\mathrm{g}$ ). The specimens were then dissected through a longitudinal incision in the ventral region for the removal of the entire digestive tract. The tract was weighed ( $\mathrm{Wt}$, in $\mathrm{g}$ ) on an analytical balance with a precision of $0.00001 \mathrm{~g}$ and conserved in $70 \%$ ethanol for the subsequent analysis of the contents. The items were analyzed under

Table 1. Environmental characterization of colleting stations where the specimens of Hemigrammus belottii were collected, Urucu river basin, central Amazonia, Brazil (Cond. $=$ Conductivity).

\begin{tabular}{|c|c|c|c|c|c|c|c|c|}
\hline \multirow{2}{*}{ Station } & \multicolumn{2}{|c|}{ pH } & \multicolumn{2}{|c|}{ Cond. $\left(\mu\right.$ s.cm $\left.{ }^{-1}\right)$} & \multirow{2}{*}{$\begin{array}{l}\text { Depth } \\
\text { (m) }\end{array}$} & \multirow{2}{*}{$\begin{array}{l}\text { Width } \\
\text { (m) }\end{array}$} & \multirow{2}{*}{$\begin{array}{l}\text { Water } \\
\text { type }\end{array}$} & \multirow{2}{*}{$\begin{array}{l}\text { Dominant } \\
\text { substrate }\end{array}$} \\
\hline & dry & wet & dry & wet & & & & \\
\hline CS1 & 6.8 & 5.85 & 31.8 & 9.26 & 1.02 & 4.2 & Still & Leaf litter \\
\hline $\mathrm{CS} 2$ & 6.9 & 5.25 & 36.8 & 11 & 0.28 & 2.54 & Still & Clay \\
\hline $\mathrm{CS} 3$ & 7.7 & 5.9 & 34.8 & 10.89 & 0.44 & 2.68 & Running & Clay \\
\hline $\mathrm{CS} 4$ & 7.1 & 5.12 & 30.3 & 10.78 & 0.16 & 1.05 & Running & Clay \\
\hline CS5 & 7.8 & 4.9 & 32.9 & 9.88 & 0.96 & 6 & Running & Clay \\
\hline CS6 & 7.9 & 5.9 & 39.9 & 7.89 & 1.4 & 8 & Running & Clay/leaf litter \\
\hline CS7 & 6.8 & 6 & 35.7 & 8.11 & 0.78 & 15.5 & Running & Clay \\
\hline $\mathrm{CS} 8$ & - & - & - & - & - & - & & \\
\hline CS9 & 6.2 & 5.75 & 33.8 & 11.9 & 0.85 & 2.7 & Running & Clay/leaf litter \\
\hline CS10 & - & - & - & - & - & - & & \\
\hline CS11 & 6.5 & 5.83 & 35.9 & 8.67 & 0.85 & 2.1 & Running & Clay \\
\hline
\end{tabular}




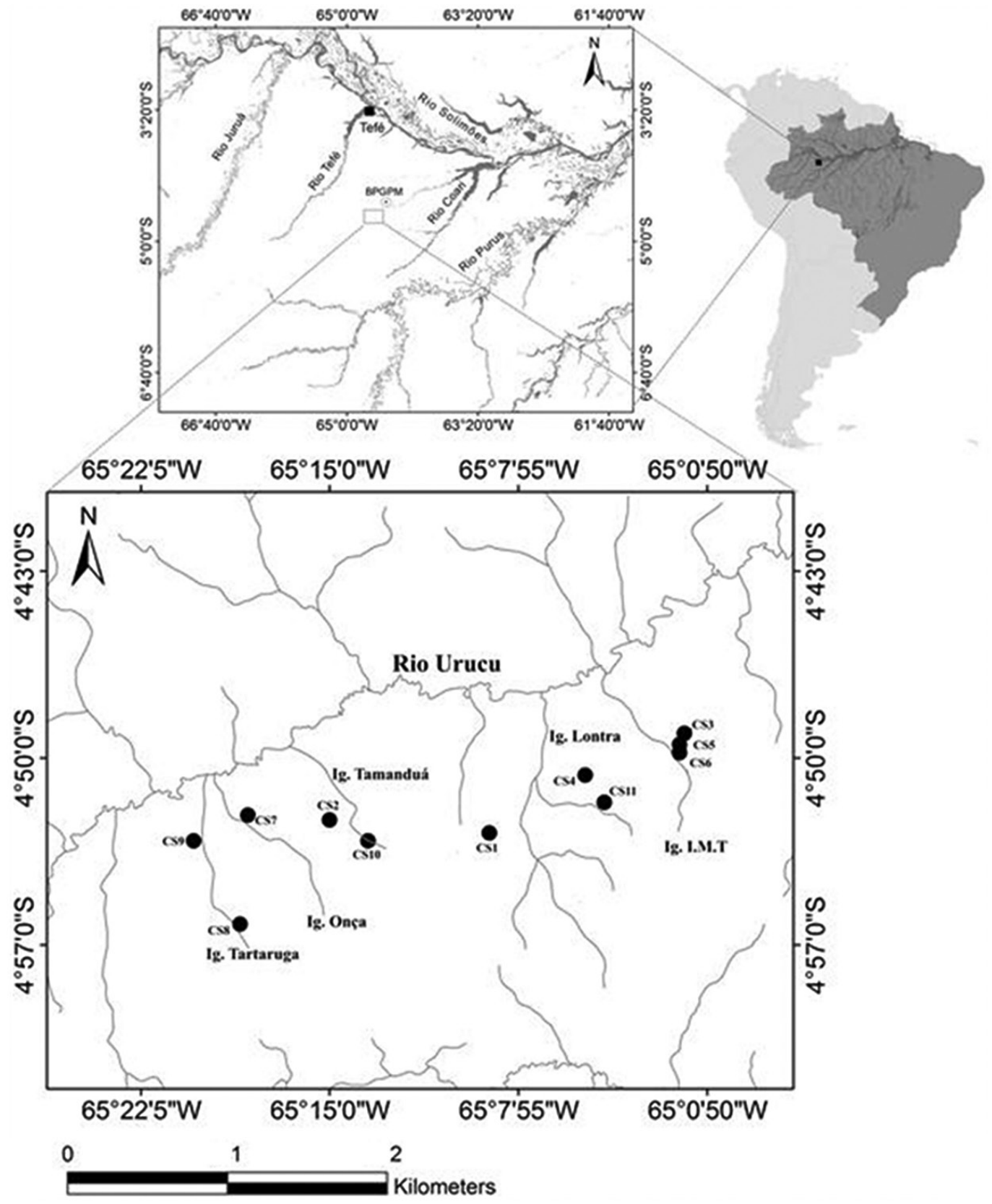

Figure 1. Location of the Urucu River basin, showing the collecting stations (CS1-11) where the Hemigrammus belottii specimens were captured.

a stereoscopic microscope for identification to the lowest possible taxonomic level, based on the specialized literature (Costa et al. 2006, Rupert \& Barnes 2005).

The intensity of resource consumption was evaluated by repletion index (RI\%) for each specimen, based on the equation $\mathrm{RI} \%=\mathrm{Pe} / \mathrm{Pt} *$ 100 , where $P e$ represents the weight of the digestive tract, in grams and $P t$ the body weight of the specimen, in grams (Zavala-Camin 1996). The RI\% values were analyzed for possible differences between dry and wet seasons based on the nonparametric Mann-Whitney test, used to test the null hypothesis $\left(\mathrm{H}_{0}\right)$ that feeding intensity was not affected by hydrologic season, with a 5\% significance level (Zar 1999).

The contribution of each item to the diet of $H$. belottii was estimated based on its frequency of occurrence $\left(\mathrm{FO}_{\mathrm{i}} \%\right.$ ), obtained by the equation $F O_{i} \%=f_{i} / N * 100$, where $f_{i}$ represents the number of stomachs containing item $i$ and $N$ is the total number of stomachs analyzed. The relative weight $\left(\mathrm{W}_{\mathrm{i}} \%\right)$ of each item was calculated by $W_{i} \%=m_{i} / N * 100$, where $m_{i}$ represents the weight in grams of item $i$ and $N$ is the total weight of all items in the stomachs (Hyslop 1980). These two methods were combined to obtain the Alimentary Index $\left(\mathrm{AI}_{i} \%\right)$, which evaluates the importance of each item to the composition of the diet of the species (Kawakami \& Vazzoler 1980, Teixeira \& Bennemann 2007), and is calculated by the formula: $A I_{i} \%=F O \% * W_{i} \% * 100 / \Sigma\left(F O \% * W_{i} \%\right)$.

To evaluate possible variations in the diet of $H$. belottii in the different igarapés of the study area and during different periods, the dietary items were grouped in five distinct categories (terrestrial insects, Arachnida, insect larvae, Crustacea, and plant fragments) and analyzed using non-metric multidimensional scaling, NMDS (Clarke \& Warwick 1994). The $\mathrm{AI}_{\mathrm{i}} \%$ values for each category were transformed into their square-roots for the calculation of a matrix of similarity based on the Bray-Curtis similarity index, run in the PRIMER ${ }^{\circledR} 6$ statistics program (Clarke \& Gorley 2001). This analysis 
calculates the distortion or "stress" between the similarity matrix and the ordination produced by the graphic representation of the axes (Clarke \& Warwick 1994).

A nonparametric analysis of similarity (two-way ANOSIM), which is analogous to an analysis of variance, was used to test the null hypotheses that neither the hydrologic season nor the spatial variation within the study area influenced the diet of $H$. belottii. This analysis was also run in PRIMER ${ }^{\circledR} 6$ (Clarke \& Gorley 2001). This analysis provides an $\mathrm{R}$ value, a comparative measure of the degree of separation of the samples, which provides the basis for the acceptance or rejection of the null hypothesis, and the probability (p) that represents the percentage risk of a type I error (Clarke \& Warwick 1994).

\section{Results}

A total of $317 \mathrm{H}$. belottii specimens were collected, with a mean standard length of $16.54 \pm 5.6 \mathrm{~mm}$. Of these, 90 individuals $(28 \%)$ had no material in their stomachs. Stomach contents were collected from 227 specimens, 136 (59\%) during the dry season, and 91(41\%) during the wet season.

A total of 26 different items were identified in the diet of the $H$. belottii from the Urucu River basin (Table 2), which was composed primarily of terrestrial insects, in particular formicids $\left(\mathrm{AI}_{\text {Formicidae }} \%=69.69\right)$ and coleopterans $\left(\mathrm{AI}_{\text {Coleoptera }} \%=6.06\right)$. It is important to note that autochthonous items were also recorded, but with reduced importance. Dipteran larvae $\left(\mathrm{AI}_{\text {Dipteran larvae }} \%=1.78\right)$ were the most abundant of these items. The variation in the RI\% values (Figure 2) indicated that the feeding intensity of $H$. belottii was three times higher during the dry season in comparison with the wet $(\mathrm{U}=644 ; \mathrm{p}<0.01)$.

The NMDS analysis, along with the ANOSIM test indicated that the relative importance of the different items was not linked to either the spatial variation of each studied igarapés of the area or with the season (R: $-0.006 ; \mathrm{p}>0.05$; Stress $=0.00)($ Figure 3$)$.

\section{Discussion}

A number of studies of Neotropical streams have emphasized the importance of the riparian vegetation for the diet of igarapé fishes, given that it is the principal source of allochthonous material for the aquatic system (Goulding 1980, Lowe-McConnell 1999). This material may represent dietary items (Sabino \& Castro 1990, Dufech et al. 2003, Tófoli et al. 2010), as recorded in the present study, or it may act indirectly by providing habitats for the aquatic invertebrates that represent a dietary resource for the fishes, such as floating logs and submerged leaf litter (Pusey \& Arthington 2003).

A number of studies in stream habitats have indicated that both autochthonous and allochthonous resources may be important in the diets of fishes (Sabino \& Castro 1990, Barreto \& Aranha 2006, Rezende \& Mazzoni 2006a, Brandão-Gonçalves et al. 2009), and that the consumption of items from different sources may be linked to a number of factors, such as the diversity of habitats, the degree of disturbance of the marginal vegetation, anthropogenic interference, and temporal variation (Ceneviva-Bastos \& Casatti 2007, Borba et al. 2008).

The presence of riparian vegetation, whether forest or shrubs, appears to be fundamental to the conservation of $H$. belottii, given

Table 2. Alimentary index (AIi\%) for the items present in the digestive tract of Hemigrammus belottii in the Urucu River basin in the central Amazonia, Brazil, during the dry and wet seasons.

\begin{tabular}{|c|c|c|c|c|}
\hline Origin/Item & Taxon or item & AI\% $\%_{\text {dry }}$ & AI\% $\%_{\text {wet }}$ & $\mathbf{A I} \%_{\text {Total }}$ \\
\hline \multicolumn{5}{|l|}{ Allochthonous } \\
\hline \multirow[t]{14}{*}{ Terrestrial insects } & & 96.124 & 99.528 & 97.926 \\
\hline & Diptera & 7.839 & 0.736 & 3.557 \\
\hline & Formicidae & 66.227 & 60.398 & 69.696 \\
\hline & Coleoptera & 11.332 & 0.924 & 6.06 \\
\hline & Hymenoptera & 0.058 & - & 0.017 \\
\hline & Psocoptera & 0.071 & $<0.001$ & 0.032 \\
\hline & Ephemeroptera & 0.312 & - & 0.093 \\
\hline & Blattodea & $<0.001$ & - & $<0.001$ \\
\hline & Heteroptera & 0.002 & 0.368 & 0.109 \\
\hline & Orthoptera & 0.113 & - & 0.034 \\
\hline & Collembola & $<0.001$ & & $<0.001$ \\
\hline & Thysanoptera & - & $<0.001$ & $<0.001$ \\
\hline & Trichoptera & - & 0.063 & 0.014 \\
\hline & Exoskeleton fragments & 8.932 & 28.651 & 17.776 \\
\hline \multirow[t]{4}{*}{ Arachnida } & & 0.877 & $<0.001$ & 0.331 \\
\hline & Araneae & 1.079 & - & 0.324 \\
\hline & Opiliones & 0.002 & - & $<0.001$ \\
\hline & Acari & 0.276 & - & 0.103 \\
\hline Autochthonous & & & - & \\
\hline \multirow[t]{5}{*}{ Imature insects } & & 2.998 & 0.471 & 1.742 \\
\hline & Ephemeroptera & - & 0.097 & 0.021 \\
\hline & Coleoptera & 0.528 & - & 0.158 \\
\hline & Diptera & 2.498 & 0.764 & 1.781 \\
\hline & Exoskeleton fragments & 0.725 & - & 0.217 \\
\hline Crustacea & Ostracoda & - & $<0.001$ & $<0.001$ \\
\hline Plant fragments & Alga & $<0.001$ & - & $<0.001$ \\
\hline
\end{tabular}




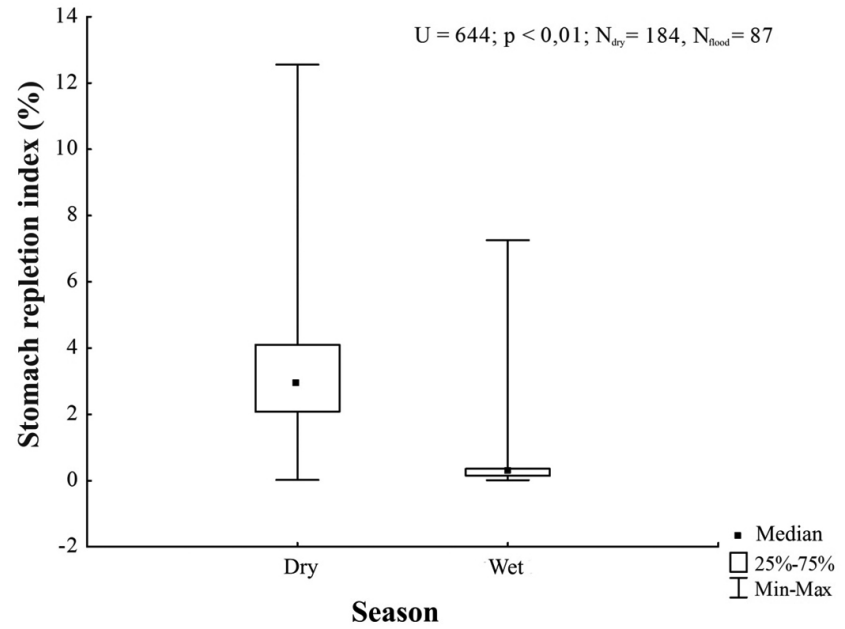

Figure 2. Seasonal variation in the repletion index (RI\%) for the Hemigrammus belottii specimens collected in the Urucu River basin, Central Amazonia, Brazil.

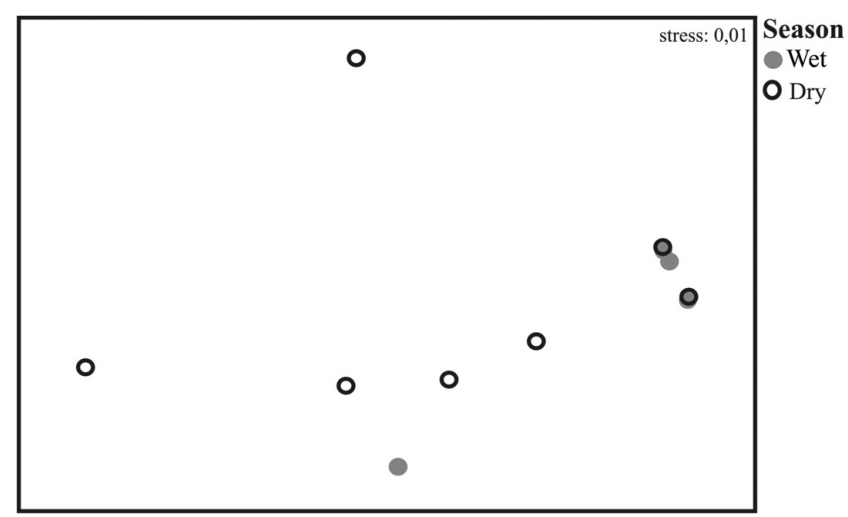

Figure 3. Ordination resulting from the non-metric multidimensional scaling (NMDS) of the variation in the diet of Hemigrammus belottii based on the specimens collected at the 11 sampling stations in the dry and wet seasons. Stress $=0.001$.

that, while an ample variety of items were consumed, the principal item ingested by the species in the Urucu basin was terrestrial insects. The order Hymenoptera, in particular the family Formicidae, is an important item in the diet of many characid species (Rezende \& Mazzoni 2005a,b, Ceneviva-Bastos \& Casatti 2007, Borba et al. 2008, Gomiero et al. 2008), including H. belottii. This taxon was the predominant item in the digestive tracts of the specimens analyzed in the present study. This may be related to the abundance of ants in tropical forests, and in particular in the central Amazon basin, where they may constitute as much as three-quarters of the biomass of the soil fauna (Fittkau \& Klinge 1973). Pimentel (2003) concluded that, in addition to providing a potentially rich source of energy for Characiforms, ants tend to become vulnerable to predation once in the water. The predominance of ants in the diet of $H$. belottii may also indicate that this species feeds on the surface of the water, given that these insects tend to float on the surface after falling into the water (Borba et al. 2008).

The abundance of food items may vary over time, and this variation may be reflected in the diets of fish species (Rezende \& Mazzoni 2005, Barreto \& Aranha 2006, Brandão-Gonçalves et al. 2009), as observed in the present study, with a higher feeding intensity being recorded during the dry season. As in the present study, many species of Characidae have shown greater feeding intensity and energy storage during periods preceding the reproductive activity peaks, aiming higher reproductive success (Braga et al. 1985, Hojo et al. 2004, Branco et al. 2005, Ballesteros et al. 2009). However, the variation may also be related to the difficulty of capturing prey during the rainy season. For example, Uieda (1995) observed sand in the stomachs of five fish species in a river in Ubatuba, São Paulo (Brazil) during the rainy season, presumably as a result of the increase in current velocity and the turbulence of the water during this period.

While a number of studies have recorded spatial and temporal variation in fish diets (Hahn et al. 1992, Motta \& Uieda 2004, Brandão-Gonçalves et al. 2009, Lima \& Behr 2010), no such pattern was recorded in $H$. belottii, probably related to the generalist behavior of the species, which appears to be typical of the characids (Bennemann et al. 2005, Silva et al. 2008, Brandão-Gonçalves et al. 2009). However, the lack of variation may also be related to the abundance of resources in Amazonian streams (Knöopel 1970).

Overall, then, Hemigrammus belottii is a generalist insectivore that feeds primarily on terrestrial prey, in particular ants (Formicidae). The species fed intensively during the dry season which is possibly related to either the breeding process or to the greater vulnerability of prey during this period. No spatial or temporal variation was observed in the diet composition, which may reflect the diversity of items ingested, and their abundance in Amazonian stream systems.

\section{Acknowledgments}

The authors are grateful to the CT-PETRO Amazônia/PT-1 network for funding the present study with resources from the Petroleum Sectorial Fund (FINEP and CNPq), Brazilian Petroleum S/A (PETROBRAS) for logistic support, and CNPq for granting an undergraduate research stipend to AFGG (process no. 123290/20104).

\section{References}

ANJOS, M.B. 2005. Estrutura de comunidades de peixes de igarapés de terra firme na Amazônia Central: composição, distribuição e características tróficas. Dissertação de mestrado, Instituto de pesquisa da Amazônia, Universidade Federal da Amazônia, Manaus.

ATAÍDE, K.R.P., BEZERRA, A.C.N. \& RIBEIRO, J.B.M. 2004. Classificação climática da bacia do Rio Urucu pelos métodos de Koppen e Thornthwaite. In Anais do XIII Congresso de Meteorologia. Fortaleza. http://www. cbmet.com/busca.php (ultimo acesso em 20/06/2011).

BALLESTEROS, T.M., TORRES-MEJIA, M. \& RAMÍRES-PENILLA, M.P. 2009. How does diet influence the reproductive seasonality of tropical freshwater fish? A case study of a characin in a tropical mountain river. Neotrop. Ichthyol. 7(4):693-700. http://dx.doi.org/10.1590/S167962252009000400019

BARRETO, A.P. \& ARANHA, J.M.R. 2006. Alimentação de quatro espécies de Characiformes de um riacho da Floresta Atlântica, Guaraqueçaba, Paraná, Brasil. Rev. Bras. Zool. 23(3):779-788.

BENNEMANN, S.T., GEALH, A. M., ORSI, M.L. \& SOUZA, L.M. 2005. Ocorrência e ecologia trófica de quatro espécies de Astyanax (Characidae) em diferentes rios da bacia do rio Tibagi, Paraná, Brasil. Iheringia, Zool. 95(3):247-254.

BORBA, C.S., FUGI, R., AGOSTINHO A.A. \& NOVAKOWSKI, G.C. 2008. Dieta de Astyanax asuncionensis (Characiformes, Characidae), em riachos da bacia do rio Cuiabá, Estado do Mato Grosso. Acta scientiarum. 30(1):39-45.

BRAGA, R.R., BORNATOWSKI, H. \& VITULE, J.R.S. 2012. Feeding ecology of fishes: an overview of worldwide publications. Rev. Fish Biol. Fish 22(4):915-929.

BRAGA, F.M.S., BRAGA, M.A.S. \& GOITEIN, S. 1985. Fator de condição e alimentação de Paralonchurus brasiliensis (Osteichthyes, Sciaenidae)

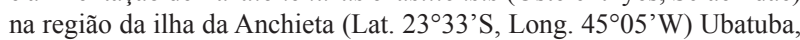
Estado de São Paulo. Naturalia 10:1-11. 
BRANCO, J.O., LUNARDON-BRANCO, M. \& VERANI, J.R. 2005. Aspectos biológicos e pesqueiros de Paralonchurus brasiliensis Steindachner, (Pisces, Sciaenidae), na Armação do Itapocoroy, Penha, Santa Catarina, Brasil. Rev. Bras. Zool. 22(4):1063-1071.

BRANDÃO-GONÇALVES, L., LIMA-JUNIOR, S.E. \& SUAREZ, Y.R. 2009. Hábitos alimentares de Bryconamericus stramineus Eigenmann, 1908 (Characidae), em diferentes riachos da sub-bacia do Rio Guiraí, Mato Grosso do Sul, Brasil. Biota Neotrop. 9(1): http://www.biotaneotropica. org.br/v9n1/en/abstract?article+bn03109012009. (último acesso em: $12 / 02 / 2013)$.

CASTRO, R.M.C. 1999. Evolução da ictiofauna de riachos sul-americanos: padrões gerais e possíveis processos causais. In Ecologia de Peixes de Riachos (E.P. Caramaschi, R. Mazzoni \& P.R. Peres-Neto, eds.). PPGEUFRJ, Série Oecologia Brasiliensis, v.6, p.139-155.

CENEVIVA-BASTOS, M. \& CASATTI, L. 2007. Oportunismo alimentar de Knodus moenkhausii (Teleostei, Characidae):uma espécie abundante em riachos do noroeste do Estado de São Paulo, Brasil. Iheringia, Zool. 97(1):7-15.

CLARKE, K.R. \& GORLEY, R.N. 2001. Software PRIMER. Plymouth, PRIMER-E.

CLARKE, K.R. \& WARWICK, R.M. 1994. Change in marine communities: an approach to statistical analysis and interpretation. Natural Environment Research Council, Plymouth.

COSTA, C., IDE, S. \& SIMONKA, C.E. 2006. Insetos imaturos. Metamorfose e identificação. Holos Ed., Ribeirão Preto.

DUFECH, A.P.S., AZEVEDO, M.A. \& FIALHO C.B. 2003. Comparative dietary of two populations of Mimagoniates rheocharis (Characidae:Glandulocaudinae) from two streams of Southern Brazil. Neotrop. Ichthyol. 1(1):67-74. http://dx.doi.org/10.1590/S167962252003000100008

ESPÍRITO-SANTO, H.M.V., MAGNUSSON, W.E., ZUANON, J., MENDONÇA, F.P. \& LANDEIRO, V.L. 2009. Seasonal variation in the composition of fish assemblages in small Amazonian forest streams: evidence for predictable changes. Freshw. Biol., 54: 536-548.

ESTEVES, K.E. \& ARANHA M.R. 1999. Ecologia trófica de peixes de riachos. In Ecologia de Peixes de Riachos (E.P. Caramaschi, R. Mazzoni \& P.R. Peres-Neto, eds.). PPGE-UFRJ, Série Oecologia Brasiliensis, v.6, p.139-155.

FITTKAU, E.J. \& KLINGE, H. 1973. On Biomass and Trophic Structure of the Central Amazonian Rain Forest Ecosystem. Biotropica 5(1):2-14. http://dx.doi.org/10.2307/2989676

GOMIERO, L.M., MANZATTO, A.G. \& BRAGA, F.M.S. 2008. The role of riverine forests for food supply for the omnivorous fish Brycon opalinus Cuvier, 1819 (Characidae) in the Serra do Mar, Southeast Brazil. Braz. J. Biol. 68(2):321-328.

GOULDING, M., 1980. The fishes and the forest: Explorations in Amazonian Natural History. University of California Press, Berkeley.

HAHN, N.S., MONFREDINHO-JÚNIOR A., FUGI, R. \& AGOSTINHO, A.A. 1992. Aspectos da alimentação do armado, Pterodoras granulosos (Ostariophysi, Doradidae) em distintos ambientes do Alto Rio Paraná. Rev. Unimar 14(suplemento):163-176.

HOJO, R.E.S., SANTOS, G.B. \& BAZZOLI, N. 2004. Reproductive biology of Moenkhausia intermedia (Eigemann) (Pisces:Characiformes) in Itumbiara Reservoir, Goiás, Brasil. Rev. Bras. Zool. 21(3):519-524.

HYSLOP, E.J. 1980. Stomach contents analysis - a review of methods and their application. J. Fish Biol. 17:411-429. http://dx.doi. org/10.1111/j.1095-8649.1980.tb02775.x

KAWAKAMI, E. \& VAZZOLER, G. 1980. Método gráfico e estimativa de índice alimentar aplicado no estudo de alimentação de peixes. Bol. Inst. Oceanogr. 29(2):205-207.
KNÖOPEL, H.A. 1970. Food of central Amazonian fishes. Contribution to the nutrient-ecology of Amazonian rain-florest-stream. Amazoniana 2:257-352.

LIMA, D.O. \& BEHR, E.R. 2010. Feeding ecology of Pachyurus bonariensis Steindachner, 1879 (Sciaenidae: Perciformes) in the Ibicuí River, Southern Brazil: ontogenetic, seasonal and spatial variations. Braz. J. Biol. 70(3):503-509.

LOWE-McCONNELL, R.H. 1999. Estudos ecológicos em comunidades de peixes tropicais. EdUSP, São Paulo.

MOTTA, R.L. \& UIEDA, V.S. 2004. Dieta de duas espécies de peixes do Ribeirão do Atalho, Itatinga, SP. Rev. Bras. Zoocienc. 6(2):191-205.

PIMENTEL, F.L. 2003. Dieta de Pyrrhulina brevis (Characiformes: Lebiasnidae) em igarapés de la Amazonía Central: Seletiva o Generalista? In Ecologia da floresta amazônica: curso de campo 2003 (E. Venticinque \& J. Zuanon, org.). PDBFF/INPA, Manaus, p.136-139.

PUSEY, B.J. \& ARTHINGTON, A.H. 2003. Importance of riparian zone to the conservation and management of freshwater fish: a review. Mar. Freshw. Res. 54:1-16. http://dx.doi.org/10.1071/MF02041

REZENDE, C.F. \& MAZZONI, R. 2006a. Disponibilidade e uso de recursos alóctones por Bryconamericus microcephalus (Miranda-Ribeiro) (Actinopterygii, Characidae), no córrego Andorinha, Ilha Grande, Rio de Janeiro, Brasil. Rev. Bras. Zool. 23(1):218-222.

REZENDE, C.F. \& MAZZONI, R. 2006b. Contribuição da matéria autóctone e alóctone para a dieta de Bryconamericus microcephalus (MirandaRibeiro) (Actinopterygii, Characidae), em dois trechos de um riacho de Mata Atlântica, Rio de Janeiro, Brasil. Rev. Bras. Zool. 23(1):58-63.

REZENDE, C.F. \& MAZZONI, R. 2005. Seasonal variation in the input of allochthonous matter in an Atlantic Rain Forest stream, Ilha Grande-RJ. Acta Limnol. Bras. 17(2):167-173.

RUPERT, E.E. \& BARNES, R.D. 2005. Zoologia dos invertebrados. 6. ed. Roca, São Paulo.

SABINO, J. \& CASTRO, R.M.C. 1990. Alimentação, período de atividade e distribuição espacial dos peixes de um riacho da Floresta Atlântica (Sudeste do Brasil). Rev. Bras. Biol. 50(1):23-36.

SILVA, C.C., FERREIRA E.J.G. \& DEUS, C.P. 2008. Diet of Bryconops alburnoides and B. caudomaculatus (Osteichthyes: Characiformes) in the region affected by Balbina Hydroelectric Dam (Amazon drainage, Brazil). Neotrop. Ichthyol. 6(2):237-242.

STRAHLER, A.N. 1957. Quantitative analysis of watershed geomorphology. Eos, Trans. Amer. Geophys. Union 38(6):913-920.

TEIXEIRA, T. \& BENNEMANN, S.T. 2007. Ecomorfologia refletindo a dieta dos peixes em um reservatório no sul do Brasil. Biota Neotrop. 7(2):67-77. http://www.biotaneotropica.org.br/v7n2/pt/ abstract?article+bn00807022007.

TÓFOLI, R.M., ALVES, G.H.Z. \& NOVAKOWSKI G.C. 2010. Uso do alimento por duas espécies simpátricas de Moenkhausia (Characiormes, Characidae) em um riacho da região Centro-Oeste do Brasil. Iheringia Zool. 100(3):201-206.

UIEDA, V.S. 1995. Comunidade de peixes de um riacho litorâneo: Composição, hábitat e hábitos. Tese de doutorado, Universidade Estadual de Campinas, Campinas.

WALKER, I. 1998. Population dynamics of Chironomidae (Diptera) in the central Amazonian blackwater river Tarumã-Mirim (Amazonas, Brasil). Oecol. Bras. 5(1):235-252. http://dx.doi.org/10.4257/oeco.1998.0501.17

WOOTTON, R.J. 1992. Fish Ecology. Ed. Chapman \& Hall, New York.

ZAR, J.H. 1999. Biostatistical Analysis. 4th ed. Prentice-Hall, Inc., Englewood Cliffs.

ZAVALA-CAMIN, L.A. 1996. Introdução aos estudos sobre alimentação natural em peixes. EdUEM, Paraná. 


\section{Appendix}

Specimens examined: Hemigrammus belottii, MPEG15025, MPEG17338-MPEG17355, MPEG17358, MPEG17360-MPEG17362, MPEG17366, MPEG17367, MPEG17370, MPEG17371, MPEG17789-MPEG17791, MPEG17795, MPEG17796, MPEG17885, MPEG17887, MPEG17888, MPEG17892, MPEG17893, MPEG17895, MPEG17896, MPEG17901, MPEG17903-MPEG17905, MPEG17907, MPEG17908, MPEG17912, MPEG17913, MPEG18073-MPEG18076. 